\title{
The effect of physical activity on level of anger among individuals with autism
}

\author{
Mehmet ILKIM ${ }^{1}$, Halil TANIR ${ }^{2}$, Mehmet ÖZDEMIR ${ }^{3}$, İbrahim BOZKURT²
}

\author{
${ }^{1}$ İnönü University, Faculty of Sports Sciences, Malatya, Turkey. \\ ${ }^{2}$ Adnan Menderes University, Faculty of Sports Sciences, Aydin, Turkey. \\ ${ }^{3}$ Selçuk University, Faculty of Sports Sciences, Konya, Turkey. \\ Address correspondence to: M. Ilkım, e-mail: mehmet.ilkim@inonu.edu.tr
}

\begin{abstract}
This study was undertaken to investigate the effect of physical activity on anger level in autistic individuals. Study sample included parents of 40 autistic children ( $n=20$ experimental and $n=20$ control) aged 10-14 years from Malatya Private Sevgi Yolu Rehabilitation Center. Three days a week for 16 weeks, the experimental group did the activities of one-hour walk, jogging, double-leg jump, and walking along a balancing beam. Individuals in the control group continued their daily routine without participating in any activity during this period. Anger levels of autistic individuals were identified using the Trait Anger and Anger Expression Inventory (TAAEI) developed by Spielberger et al. (1983) and adapted to Turkish by Özer (1994). The inventory was completed by the parents of the individuals both in the experimental and control groups following the 16-week activity program. The collected data was analyzed at the significance level of 0.05 (i.e. a confidence level of $95 \%$ ) in SPSS version 22.0. Statistical analysis indicated significant differences between trait anger, controlled anger, expressed anger and suppressed anger scores $(\mathrm{p}<0.05)$. The results showed that anger levels of the autistic individuals participating in the physical activity program were lower and the physical activity in autistic individuals helped anger control. It is recommended that autistic individuals participate in low intensity activities for at least 3 days a week. By teaching autistic individuals how to keep their anger under control, interpersonal and family conflicts, feelings of guilt, low self-esteem and some behavioral (e.g. shyness, crying, unhappiness, anorexia, bulimia) and physiological problems (e.g. sweating, headache, difficulty in breathing) can be avoided.
\end{abstract}

Keywords: Physical activity, autism, level of anger

\section{INTRODUCTION}

Defined as an internal state involving various degrees of and interactions between physiological, cognitive, motoric, and verbal components, anger is one of the five basic emotions that are comprised of anger, happiness, sadness, fear, and hatred. The feeling of anger often experienced by many people in everyday life is a normal and universal feeling, not a negative one as perceived at first sight. Although it is a highly healthy feeling when expressed in a constructive manner, anger can indeed become harmful for the person himself and for the others if it is not expressed properly (2).

Anger, which is an important part of personality and arises in interpersonal relationships, can guide the behaviors of individuals (3). Among the causes of anger are frustration, unfair treatment, physical injuries, harassment, disappointment, aggression and threats (6).
The way anger is expressed differs from person to person. These expressions are measured as angerin, anger-out and anger-control. Anger-in refers to the tendency to suppress the thoughts and feelings that arouse anger; anger out is the tendency to show aggressive behaviors towards the people or objects around; and anger-control is the ability to control angry feelings or the expression of the anger towards others (13).

Anger during adolescence is a serious and a common problem with negative consequences for both the individual and society (2). Experienced intensely during adolescence, the feeling of anger is one of the basic feelings such as love, fear and enjoyment. Anger is an emotional reaction brought by oppression, frustration, disappointment, hurt, fear and the violation of our rights. Though anger is a natural feeling, it leads to aggression and negative behaviors when not kept under control or managed properly (5). 
Behavior disorders involving anger reaches its peak in adolescence (16). In this period, individuals can lose their temper and even harm themselves due to their inability to express themselves. Such behavioral disorders are more frequent among disabled people (15).

Social competence and peer acceptance are becoming increasingly important in adolescence. In this period, individuals with disabilities are more sensitive to the negative consequences of having few or no friends at all. The need to develop intimacy that is felt increasingly in adolescence seems to be fulfilled only by peer relations. Lack of these relationships and friendships results in withdrawal, inadequacy in social skills, avoidance of social risks, and serious emotional behavioral problems in adolescents (1). Disabled individuals therefore are likely to lose their temper quickly and hurt themselves and others around.

Physical activity can encourage disabled individuals to improve the skills necessary to live in the society. It can help them participate in social activities together with other healthy peers. Thus, anger control can be achieved by reducing aggressive drives in disabled individuals (12). For this reason, the current study was undertaken to determine the effect of a 16-week physical activity program ( 1 hour 3 days a week) on anger level of autistic adolescents aged 10-14 years.

\section{MATERIAL \& METHOD}

Study sample included parents of 40 autistic children $(\mathrm{n}=20$ experimental and $\mathrm{n}=20$ control) aged 10-14 years from Malatya Private Sevgi Yolu Rehabilitation Center. Three days a week for 16 weeks, the experimental group did the activities of one-hour walk, jogging, double-leg jump, and walking along a balancing beam. Individuals in the control group continued their daily routine without participating in any activity during this period. Anger levels of the autistic individuals were identified using the Trait Anger-Anger Expression Style Inventory (TAEI). The inventory was completed by the parents of the individuals both in the experimental and control groups at the end of 16-week activity program.

\section{Data Collection Tools}

\section{Trait Anger-Anger Expression Inventory (TAAEI)}

Anger levels of the autistic individuals were identified using the Trait Anger and Anger
Expression Inventory (TAAEI) developed by Spielberger et al. (13) and adapted to Turkish by Özer (10). TAAEI can be administered to adolescents and adults in order to determine the anger expression styles of students. There is no time limit to fill out the inventory, which consists of 34 items rated on a 4-point Likert-scale: not at all (1 point), somewhat (2 points), moderately so (3 points), very much so (4 points). First 10 items measure trait angry, and the next 24 items measure the expression of anger. Trait anger refers to how one feels himself/herself generally and how intensely a s/he experiences anger. Total scores range from 10 to 40 points. Anger Expression Scale includes three subscales; anger-in (Items 13, 15, 16, 20, 23, 26, 27 and 31), Anger-out (Items 12, 17, 19, 22, 24, 29, 32 and 33) and anger-control (items 11, 14, 18, $21,25,28,30$ and 34). Total scores range between 8 and 32 points. The Cronbach Alpha value for the original version is between 0.77 and 0.88 . For the Turkish version, Cronbach Alpha values were 0.84 for the "anger-control", 0.78 for "anger-out" and 0.62 for "anger-in" (10).

\section{Statistical Analysis}

The data collected were analyzed at the significance level of 0.05 (i.e. a confidence level of $95 \%$ ) in SPSS version 22.0. The normality of the data was assessed using Kolmogorov Smirnov test, which confirmed the normality of the data. Independent Sample $\mathrm{T}$ Test therefore was used to determine whether the difference between two independent groups was meaningful.

\section{RESULT}

As can be seen in Table 1. students in the experimental and control group were compared regarding their trait-anger, anger-control, anger-out and anger-in scores and comparison of the groups revealed a significant difference in favor of those in the experimental group $(\mathrm{p}<0.05)$. 
Table 1. Comparison of experimental and control groups regarding their level of anger

\begin{tabular}{|c|c|c|c|c|c|c|c|}
\hline \multirow{2}{*}{ Variables } & \multirow{2}{*}{ Groups } & \multirow{2}{*}{$\mathrm{N}$} & \multirow{2}{*}{$X$} & \multirow{2}{*}{ Sd } & \multirow{2}{*}{ Serror } & \multicolumn{2}{|c|}{$t$ test } \\
\hline & & & & & & $t$ & $\mathrm{p}$ \\
\hline Trait anger & Experimental & 20 & 38.35 & 2.62 & 0.58 & - & $0.000^{*}$ \\
\hline \multirow{2}{*}{$\begin{array}{l}\text { Anger- } \\
\text { control }\end{array}$} & Experimental & 20 & 24.75 & 2.40 & 0.53 & \multirow{2}{*}{16.645} & \multirow{2}{*}{$0.000^{*}$} \\
\hline & Control & 20 & 12.75 & 2.14 & 0.48 & & \\
\hline Anger-out & Experimental & 20 & 13.85 & 1.72 & 0.38 & - & $0.000^{*}$ \\
\hline \multirow{2}{*}{ Anger-in } & Experimental & 20 & 16.15 & 2.60 & 0.58 & - & \multirow{2}{*}{$0.000^{*}$} \\
\hline & Control & 20 & 24.05 & 1.23 & 0.27 & 12.271 & \\
\hline
\end{tabular}

${ }^{*} \mathrm{p}<0.05$

\section{DISCUSSION \& CONCLUSION}

Autism is a behavioral syndrome that is accompanied by stereotype behavioral patterns and characterized by deficits in communication and social interaction. It is considered a complex and genetically heterogeneous disease, like many neuropsychiatric disorders (8).

Behavioral and sensory problems are common in autistic individuals. Irritability, self-injurious behaviors and tantrums are some common behavioral problems in children and adolescents with autism $(7,14)$. These problems make the lives of autistic individuals and their families difficult, preventing these autistic individuals from acquiring new skills and interacting with their environment (4).

It is emphasized that the main causes lying in problem behaviors are social and communicational in nature. It is noted these behaviors emerge for the purpose of attracting attention, avoiding unwanted environment or situation and achieving the desired result. In line with this view, it is believed that the problem behaviors in autistic individuals arise due to difficulty to communicate or form relationships with others (4).

Physical activity can be used as a way of dealing with such problems. It is known for sure that physical activity plays an important part in the lives of individuals with autism which is a neurological disorder that falls under the umbrella of pervasive developmental disorder and affects the structure or functioning of the brain (11). Physical activity contributes to social adjustment and skill development in autistic individuals and increases life quality by reducing depression (9).

It is deemed that disabled people can keep their anger under control more easily when they benefit from increased social adjustment skills and comfortably involve in an interaction with typically developing peers thanks to physical activity, exercise and sports. Conducted to determine the effect of physical activity on the level of anger in autistic individuals, the current study found a significant difference between experimental and control group students regarding trait-anger, angercontrol, anger-out and anger-in scores in favor of the experimental group (Table 1). Accordingly, a decrease was observed in trait-anger, anger-out and anger-in scores and an increase in anger-control scores following the physical activity program administered to the autistic individuals in the experimental group.

The results of the current study showed that autistic individuals participating in the physical activity program had lower levels of anger and physical activity contributed to anger control in autistic individuals. For this reason, autistic individuals should participate in low-intensity activities for at least 3 days a week. Thus, by teaching autistic individuals how to keep their anger under control, interpersonal and family conflicts, feelings of guilt, low self-esteem and some behavioral (e.g. shyness, crying, unhappiness, anorexia, bulimia) and physiological problems (e.g. sweating, headache, difficulty in breathing) can be avoided.

\section{Acknowledgement}

This study was submitted as an oral presentation during 3rd International Physical Education and Sports Congress for The Disabled on 20-21 October 2017, Konya, Turkey proceeding book, 90.

\section{REFERENCES}

1. Akçamete G, Ceber H. Kaynaştııılmış sınıflardaki işitme engelli ve işiten öğrencilerin sosyometrik statülerinin karşılaştırmalı olarak incelenmesi. Ankara Üniversitesi Ĕ̆itim Bilimleri Fakültesi Özel Eğitim Dergisi, 1999; 2(3): 64-74.

2. Cenkseven F. Öfke yönetimi becerileri programının ergenlerin öfke ve saldırganlık düzeylerine etkisi. Egitim Bilimleri ve Uygulama, 2003; 2(2): 153-167. 
3. Certel Z, Bahadır Z. Takım sporu yapan sporcularda benlik saygısı ve sürekli öfke ve öfke ifade tarz ilişkisinin incelenmesi. Selçuk Üniversitesi Beden Eğitimi ve Spor Bilim Dergisi, 2012; 14(2): 157-164.

4. Çopuroğlu YC. Mengi A. Toplumsal dişlanma ve otizm. Electronic Turkish Studies, 2014; 9(5):607-626.

5. Duran Ö, Eldeleklioğlu J. Öfke kontrol programının 15 ve 18 yaş arası ergenler üzerindeki etkililiğinin araştırılması. Gazi Üniversitesi Gazi Eğitim Fakültesi Dergisi, 2005; 25(3):267280.

6. Kökdemir H. Öfke ve öfke kontrolü. Pivolka, 2004; 3(12): 7-10.

7. Minshawi NF. Behavioral assessment and treatment of selfinjurious behavior in autism. Child \& Adolescent Psychiatric Clinics of North America, 2005; 17(1): 875-886.

8. Odabaşıoğlu G, Genç Y, Öztürk Ö. Otistik hastalarda kendine zarar verme davranışında naltrekson tedavisi ve iki olgu sunumu. Klinik Psikofarmakoloji Bülteni, 2009; 19(4): 431-435.

9. Orsmond GI, Krauss MW, Seltzer MM. Peer relationships and social and recreational activities among adolescents and adults with autism. Journal of Autism and Developmental Disorders, 2004; 34(3): 245-256.
10. Özer AK. Öfke, kaygı ve depresyon eğilimlerinin bilişsel alt yapısıyla ilgili bir çalışma. Türk Psikoloji Dergisi, 1994; 9(31): 2-35.

11. Sarol H. Uyarlanmış rekreasyonel fiziksel aktivitenin otizmli bireylerin yaşam kalitesi üzerine etkisi. Doktora Tezi, Gazi Üniversitesi Sağlık Bilimleri Enstitüsü, Ankara, 2013.

12. Sonuç A. Zihinsel engellilerde sporun öfke düzeyine etkisi, Yüksek lisans Tezi, Karamanoğlu Mehmetbey Üniversitesi Sosyal Bilimler Enstitüsü, Karaman, 2012.

13. Spielberger CD. Assessment of anger: the state-trait anger expression scale. Advances in Personality Assessment, 1983; 3 (1): 112-134.

14. Stigler KA., McDougle CJ. Pharmacotherapy of irritability in pervasive developmental disorders. Child and Adolescent Psychiatric Clinics of North America, 2008; 17(4): 739-752.

15. Şipal R. Zihinsel engellilerde davranış bozuklukları, Yüksek lisans Tezi, Hacettepe Üniversitesi, Sosyal Bilimler Enstitüsü, Ankara, 2010.

16. Yıldız M. Farklı liglerde yer Alan futbolcuların kişilik tipleri ile sürekli öfke, öfke ifade tarzlarının incelenmesi, Doktora Tezi, Gazi Üniversitesi, Sağlık Bilimleri Enstitüsü, Ankara, 2008. 